\title{
Physiological and Subjective Responses Associated to Physical and Mental Load in a Simulated Task
}

\author{
Respuestas fisiológicas y subjetivas \\ asociadas a la carga física y mental \\ en una tarea simulada
}

\section{Respostas fisiológicas e subjetivas associadas à carga física e mental em uma tarefa simulada}

\author{
Juan Luis Hernández Arellano*1; \\ Aidé Aracely Maldonado Macías; \\ César Omar Balderrama Armendáriz ${ }^{1}$
}

Received: October 15, 2017 / Accepted: November 14, 2017

Doi: http://dx.doi.org/10.12804/revistas.urosario.edu.co/revsalud/a.6843

To cite this article: Hernández-Arellano JL, Maldonado-Macías AA, Balderrama-Armendáriz CO. Physiological and Subjective Responses Associated to Physical and Mental Load in a Simulated Task. Rev Cienc Salud. 2018; 16(especial): p. 52-63 .

Doi: http://dx.doi.org/10.12804/revistas.urosario.edu.co/revsalud/a.6843

\section{Abstract}

Objective: To develop a quasi-experimental study to know the changes in physiological responses and perceived efforts of a group of fifteen healthy students that performed a simulated task related with the operation of a cNc lathe in a lab environment. Materials and Methods: The participants were asked to randomly complete a total of eight sessions including single and combined test of physical and mental load. Low/High Physical Load and Low/ High Mental Load were established as independent variables. Heart rate, physical performance, mental performance, and effort perception were established as dependent variables. Conclusions: High load levels have a significant effect on the heart rate increasing, but not in the perception of effort. High levels of mental load have a significant effect on physical and mental performance.

Keywords: physical effort, mental effort, physical performance, mental performance, task simulation. 


\section{Resumen}

Objetivo: desarrollar un estudio quasi-experimental para conocer los cambios en las respuestas fisiológicas y esfuerzos percibidos en un grupo de quince estudiantes sanos que realizaron una tarea simulada relacionada con la operación de un torno $\mathrm{cNc}$ en ambiente de laboratorio. Materiales y métodos: los participantes completaron un total de ocho sesiones que incluyeron pruebas individuales y combinadas de esfuerzo físico y mental. La Carga Mental Baja/Alta y Carga Física Baja/Alta fueron establecidas como variables independientes. Frecuencia cardiaca, desempeño físico, desempeño mental y la percepción de esfuerzo fueron establecidas como variables dependientes. Conclusiones: los niveles altos de carga física tienen un efecto significativo en el incremento de la frecuencia cardiaca, pero no en la percepción de esfuerzo. Los niveles altos de carga mental tienen un efecto significativo en el desempeño físico y mental.

Palabras clave: esfuerzo físico, esfuerzo mental, desempeño físico, desempeño mental, tarea simulada.

\section{Resumo}

Objetivo: desenvolver um estudo quase-experimental para conhecer as mudanças nas respostas fisiológicas e esforços percebidos em um grupo de 15 estudantes saudáveis que realizaram uma tarefa simulada relacionada com a operação de um torno cNc em ambientes de laboratório. Materiais e métodos: os participantes completaram um total de 8 sessões que incluíram provas individuais e combinadas de esforço físico e mental. A Carga Mental Baixa/Alta e a Carga Física Baixa/Alta foram estabelecidas como variáveis independentes. Frequência cardíaca, desempenho físico, desempenho mental e a percepção de esforço foram estabelecidas como variáveis dependentes. Conclusões: os níveis altos de carga física têm um efeito significativo no incremento da frequência cardíaca, mas não na percepção de esforço. Os níveis altos de carga mental têm um efeito significativo no desempenho físico e mental.

Palavras-chave: esforço físico, esforço mental, desempenho físico, desempenho mental, tarefa simulada.

\section{Introduction}

W

ith the implementation of new, better, and more sophisticated technologies, the effort performed by workers has had significant changes (1-4), and now the workers perform to complex tasks demanding combined physical and mental efforts (2). A few years ago, workers performed only physical tasks; in contrast, today it is possible to find jobs where physical effort is practically zero, for example, office work, control room operation, among others.

The work/job/activities/tasks developed by the advanced manufacturing technology (AMT) operators are considered complex (4). One example of complex work is the operation of lathes of computer numerical control ( $\mathrm{CNC}$ ). In this type of work, the operators must develop both, physical (load and unload parts to/from the machine) and mental tasks (change of model, parameter setting, and inspection). Some studies have concluded that the duality of tasks can generate diverse fatigue symptoms $(2,4,5)$.

Because manipulating variables (for example: mental workload, heart rate, handled weight, among others) in industrial environments to get data is complex and practically impossible, the measurement of physiological indices in these conditions has been relatively 
unexplored. In contrast, it is common to simulate work conditions in lab settings. For example, some authors have developed research in laboratory environments where the effects of physical and mental fatigue have been analyzed in certain circumstances (2, 6-9). Although lab experiments have important limitations such as not consider all the stimuli, simulated time is shorter than a working day, and it is difficult to reach the external validity, in ergonomics, lab experiments are a common practice to explore the behavior of variables to explain certain phenomena or constructs. However, simulated tasks in the cited studies are different from those performed by lathes operators.

The general objective of this research is to simulate, in a lab environment, the physical and mental load in two levels (low and high) to know the effects on heart rate (HR), effort perception (ЕP), physical performance (PP), and mental performance (MP). The specific objectives are as follows:

- To quantify heart rate (HR), effort perception (EP), and physical performance (PP) when physical load (low and high) is simulated.

- To quantify the heart rate (HR), effort perception (ЕP), and physical performance (PP) when mental load (low and high) is simulated.

- To quantify the heart rate (HR), effort perception (ЕP), physical performance (рР), and mental performance (мг) when mental load (low and high) and physical load (low and high) are simulated in combination.

\section{Materials and methods}

\section{Study Design}

In order to quantify the physiological responses of mental and physical load stimulation a quasi-experimental, descriptive, cross-sectional, and correlational study design was performed in lab settings.

\section{Sample}

A convenience sample was chosen according to the following inclusion criteria:

- Being a student of the Autonomous University of Ciudad Juarez.

- Not having heart and respiratory problems, hypertension or injury in the last year prior to the experiment.

- Non-smokers.

- Having not drunk alcohol two days before the sessions. 
During the study, participants could be excluded if they suffer an injury in upper or lower limbs, presenting a mental problem, or miss more than two sessions being unable to reschedule. The subjects wore tennis shoes, jeans, cotton shirt, and cotton socks. At the end of the session, participants received a small gift.

\section{Variables}

\section{Independents}

Levels of physical and mental load considered the proposal of DiDomenico (2) who stablished values/scores for these two variables. As a result, two independent variables were manipulated, physical load and mental load. For low physical load (LPL) participants manipulated/ handed a 10-lb. weight disc, while for high physical load (HPL) a 20-lb. weight disc was used. For low mental load (LML) participants solved addition and subtraction arithmetic problems, while for high mental load (нмL), participants solved multiplication and division arithmetic problems.

\section{Dependents}

The values of four dependent variables were recorded. Heart rate (HR) was recorded using the heart rate monitor Suunto software. The physical performance was measured counting the number of times that participants moved the disc. The mental performance was measured as the ratio of the questions answered correctly divided between the number of questions answered. Effort perception was assessed using the 6-20 Borg rating of perceived exertion (RPE) (10). Participants were asked every minute during the test about their perception of global efforts performed to complete the assigned tasks (see table 1).

Table 1. Borg Scale 6-20

\begin{tabular}{cccc}
\hline Value & Effort interpretation & Value & Effort interpretation \\
\hline 6 & No exertion at all & 14 & \\
\hline 7 & Extremely light & 15 & Hard (heavy) \\
\hline 8 & & 16 & \\
\hline 9 & Very light & 17 & Very hard \\
\hline 10 & & 18 & Extremely hard \\
\hline 11 & Light & 19 & Maximal exertion \\
\hline 13 & & 20 & \\
\hline
\end{tabular}

*The variables considered in the study are shown in table 2. 
Table 2. Variables of the Study

\begin{tabular}{cccccc}
\hline \multicolumn{2}{c}{ Independent } & \multicolumn{2}{c}{ Dependent } \\
\hline Name & Levels & Code & Name & Measure unit & $\begin{array}{c}\text { Co- } \\
\text { de }\end{array}$ \\
\hline Low Physical Load & $10 \mathrm{lb}$ & LPL & Heart rate & (bpm) & (HR) \\
\hline High Physical Load & $20 \mathrm{lb}$ & HPL & Effort perception & $6-20$ & (ЕP) \\
\hline Low Mental Load & $\begin{array}{c}\text { Addition and } \\
\text { subtraction }\end{array}$ & LML & Mental performance & \# correct answers/\# questions & (MP) \\
\hline High Mental Load & $\begin{array}{c}\text { Multiplication } \\
\text { and division }\end{array}$ & HML & Physical performance & \# of movements & (PP) \\
\hline
\end{tabular}

\section{Materials}

he following materials were used in the development of the experiment:

- Suunto heart rate monitor wireless band

- Suunto software training manager V 2.2.0.8

- Two circular disks of $10 \mathrm{lb}$ and $20 \mathrm{lb}$ for testing low and high physical load, respectively.

- Portable computer

- Desktop computer

\section{Methods}

Once the subjects arrived at the lab, participants read and signed a consent form to accept their voluntary participation. Next, in a private room, the participants set the heart rate band on their chest. To stabilize the heart rate signal, participants remained seated for five minutes. When the heart rate-computer communication was confirmed, the test was ready to start.

Before starting, a research assistant explained the test activities, and two full series of the cycle were developed. Those data were eliminated from the data analysis. Every minute, participants were asked about their effort perception based on the Borg RPE scale (6-20) (10). Figure 1 shows the layout developed in the ergonomics lab at the Autonomous University of Ciudad Juarez where the experiment was conducted. 


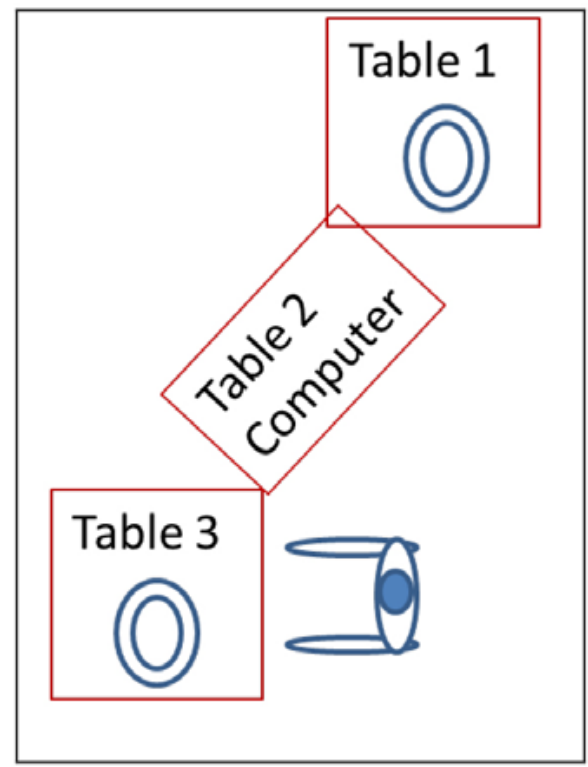

Figure 1. Layout Experiment

Because the design of the experiment involves testing with single and combined efforts, in four sessions, participants developed single effort tests. In the remaining four sessions, combined efforts tests were performed. To avoid fatigue effects, only one session was programed per day. Hereunder, test conditions are described.

\section{Single Test}

The sequence of activities performed in the single effort is shown in table 3. Four different sequences were developed using a Latin square array (see table 4).

Table 3. Activities Developed in Single Effort

\begin{tabular}{lrr}
\hline Step & Only physical activities & Only mental activities \\
\hline 1 & $\begin{array}{c}\text { Place the elbows at 90-degree position, back straight, } \\
\text { and using both hands, take the disk in point 1 }\end{array}$ & Stand in front of point 2 \\
\hline 2 & Walk 2 meters to point 3 & Read the sentence (arithmetic problem) in the screen \\
\hline 3 & Leave the disk in the point & Answer the arithmetic problem using the keyboard \\
\hline 4 & $\begin{array}{c}\text { Place the elbows at 90-degree position, back straight, } \\
\text { and using both hands, take the disc in the point 3 }\end{array}$ & Read and answer next arithmetic problem \\
\hline 5 & Walk 2 meters to point 1 & Repeat the sequence for 7 minutes \\
\hline 6 & Leave the disk in point 1 & \\
\hline 7 & Repeat the sequence for 7 minutes & \\
\hline
\end{tabular}


Table 4. Latin Square Array for Individual Efforts Tests

\begin{tabular}{ccccc}
\hline Day & Sequence 1 & Sequence 2 & Sequence 3 & Sequence 4 \\
\hline First & LPE (1) & LME (2) & HPE (3) & HME (4) \\
\hline Second & LME (2) & HPE (3) & HME (4) & LPE (1) \\
\hline Third & HPE (3) & HME (4) & LPE (1) & LME (2) \\
\hline Fourth & HME (4) & LPE (1) & LME (2) & HPE (3) \\
\hline
\end{tabular}

\section{Combined Test}

The sequence of activities performed in the combined effort tests is shown in table 5. Four different sequences were developed using a Latin square array (see table 6).

Table 5. Activities Developed in the Combined Efforts Tests

\begin{tabular}{cc}
\hline Step & Activities \\
\hline 1 & Stand in front of point 2 \\
\hline 2 & Read the arithmetic problem on the screen \\
\hline 3 & Answer the arithmetic problems using the keyboard \\
\hline 4 & Walk 1 meter to point 1 \\
\hline 5 & Place the elbows at 90-degree position, back straight \\
\hline 6 & Walk 2 meters to point 3 \\
\hline 8 & Weave the disc in point 3 \\
\hline 9 & Wead the arithmetic problems in the screen \\
\hline 10 & Answer the arithmetic problems using the keyboard \\
\hline 11 & Walk 1 meter to point 3 \\
\hline 12 & Repeat the sequence for 7 minutes \\
\hline
\end{tabular}

Table 6. Sequence of the Combined Tests

\begin{tabular}{ccccc}
\hline Day & Sequence 5 & Sequence 6 & Sequence 7 & Sequence 8 \\
\hline Fifth & LPE - LME (1) & HPE - HME (2) & LME - HPE (3) & HME - LPE (4) \\
\hline Sixth & HPE - HME (2) & LME - HPE (3) & HME - LPE (4) & LPE - LME (1) \\
\hline Seventh & LME - HPE (3) & HME - LPE (4) & LPE - LME (1) & HPE - HME (2) \\
\hline Eighth & HME - LPE (4) & LPE - LME (1) & HPE - HME (2) & LME - HPE (3) \\
\hline
\end{tabular}




\section{Data Analysis}

Tests of normality of heart rate data were performed using the Anderson Darling test.

1 Paired T-test was used for data comparisons between the sample. The nonparametric comparisons were made using the Wilcoxon Rank test. All data were captured in Excel software and then exported to SPSS v17 software for analysis. A significance level of 0.05 was used for all comparisons and hypothesis testing performed.

\section{Results}

\section{Sample}

A total of 15 volunteer students (10 men and 5 women) participated in the study. All of them with no apparent health problems. The average age was 23.4 years $( \pm 2.27)$, the mean weight was $65.8 \mathrm{~kg}$ ( \pm 8.81$)$, height $165.3 \mathrm{~cm}( \pm 11.07)$. The 15 participants completed the 8 sessions of the experiment.

\section{Heart Rate}

Single test HPE and the combinations HPE-LME and HPE-HME yielded the highest values of heart rate being significantly higher $(p<0.05)$ than those that do not include HPE. In contrast, the single test LME and the combination HME-LPE got the lowest values of heart rate (see figure 2).

\section{Heart Rate (BPM)}

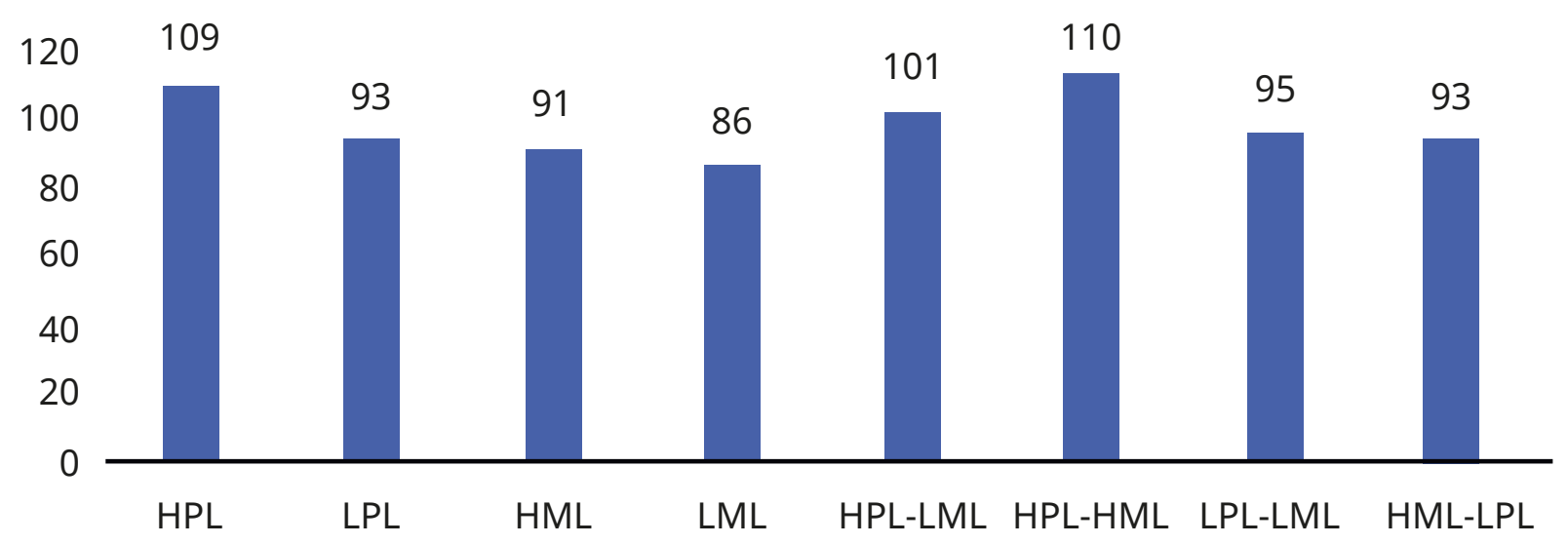

Figure 2. Heart Rate Results 


\section{Effort Perception}

In general, tests that include HPE got the highest values of effort perception. However, no significant differences among the effort perception were found ( $p>0.05$ ) in the eight tests (see figure 3 ).

Effort Perception

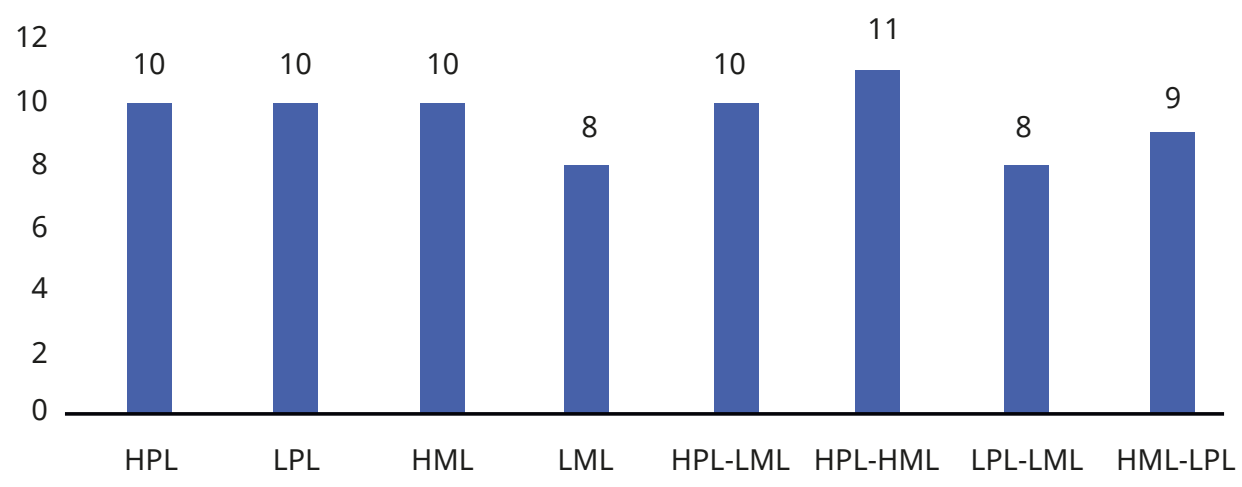

Figure 3. Effort Perception Results

\section{Performance}

For mental performance, results for tests without HME are, in average, $20 \%$ higher than tests including this condition. For example, LME, LPE-LME, and HPE-LME scored 93\%, 95\%, and 95\% efficiency, respectively, being significantly higher than the values obtained for the remaining five tests ( $p$ <0.05) (see figure 4 and table 7).

\section{Mental performance}

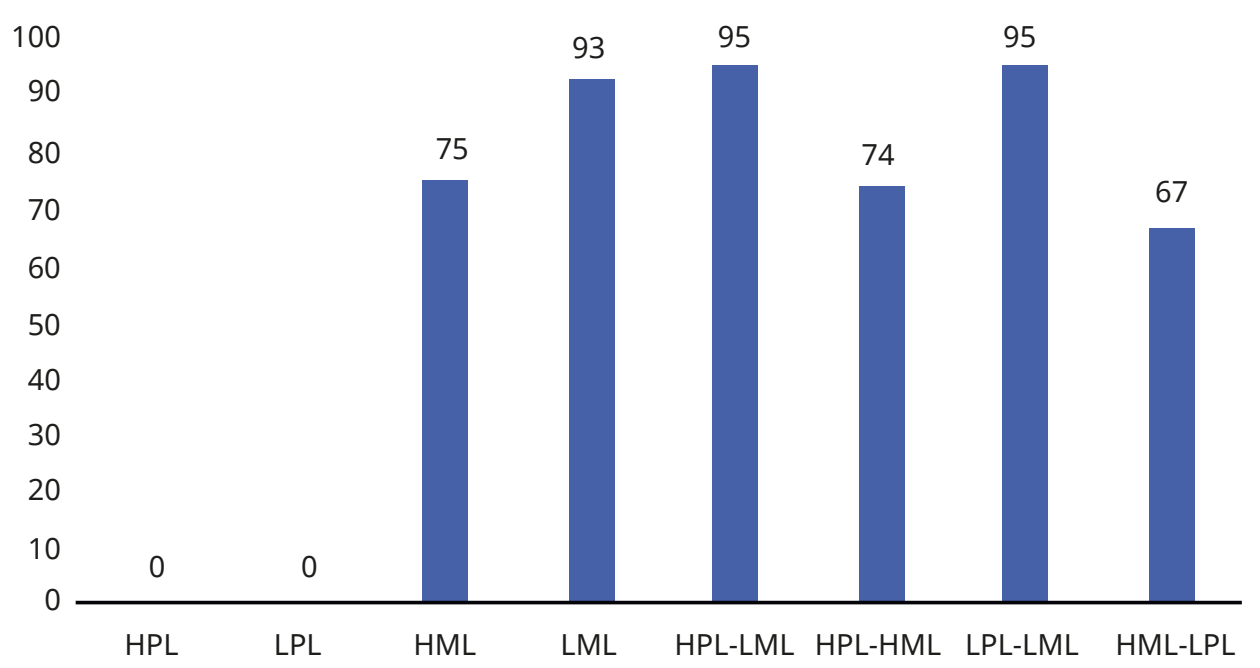

Figure 4. Mental Performance Results.

Data expressed in percentages. 
The results of physical performance showed a similar behavior when HME is not present. For example, HPE, LPE, LPE-HPE, LPE-LME scored 35, 42, 20 and 20 moves, respectively, being significantly higher than the values obtained for the remaining tests $(p<0.05)$ (see figure 5 and table 7).

\section{Physical perfomance}

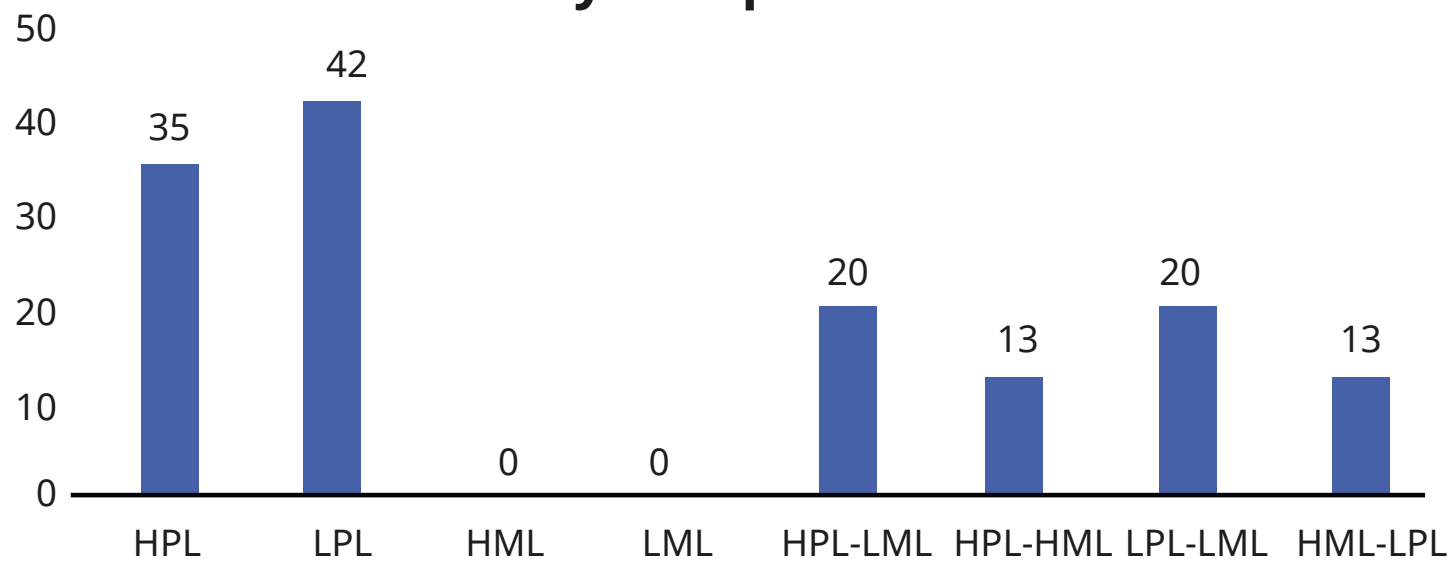

Figure 5. Physical Performance Results

Table 7. Global Results

\begin{tabular}{ccccc}
\hline Test & $\begin{array}{c}\text { Heart Rate } \\
(\text { BPM })\end{array}$ & $\begin{array}{c}\text { Effort } \\
\text { Perception }\end{array}$ & $\begin{array}{c}\text { Mental } \\
\text { Performance }\end{array}$ & $\begin{array}{c}\text { Physical } \\
\text { Performance }\end{array}$ \\
\hline HPE & 109 & 10 & NA & 35 \\
\hline LPE & 93 & 10 & NA & 42 \\
\hline HME & 91 & 10 & $75 \%$ & NA \\
\hline LME & 86 & 8 & $93 \%$ & NA \\
\hline HPE-LME & 101 & 10 & $95 \%$ & 20 \\
\hline HPE-HME & 110 & 11 & $74 \%$ & 13 \\
\hline LPE-LME & 95 & 8 & $95 \%$ & 20 \\
\hline HME-LPE & 93 & 9 & $67 \%$ & 13 \\
\hline
\end{tabular}




\section{Discussion}

ccording to the results, the presence of levels of load considered as high increases significantly - 1 the heart rate. In this case, high physical load was represented by a disk of 20-lb. For example, tests where high physical load was present got at least 14 bpm higher than others.

On the contrary, no significant differences in effort perception for all tests were found. In this case, the most probable cause was the short duration of the test (only $7 \mathrm{~min}$ ). However, the study of DiDomenico (11) found significant differences in the effects caused by the manipulation of the physical and mental load with only five minutes of simulation. Duration of the experiment is the most relevant limitation of this study. As mentioned above, some lab experiments have been successful with short time of simulation. In this specific case, another variable influencing the outcomes was the rate/speed the participants used to complete the task, that is, they were not asked to complete the study in a determined time, on the contrary, participants performed the tasks at their own pace.

The presence of high mental load decreased significantly the values of mental and physical performance getting scores between 18 and $28 \%$. The decrease of the mental performance is mainly due to the level of complexity of the arithmetic tasks where participants solved compounds statements of multiplication and division for high mental load.

For the case of physical performance, reduction in the number of movements is attributable to the time used by the participants to answer the questions of the mental load being higher for the high mental load than low mental load. As a result, high mental load got a significant decrease in the number of movements.

Findings of this study show the importance of the load levels. High load levels (physical and/ or mental) have an important effect on physiological indices (i.e. heart rate) and performance. In an effort to improve the productivity, companies should analyze current workload levels, design new tasks, and implement lower levels of workload.

\section{References}

1. Mital A, Pennathur A. Advanced Technologies and Humans in Manufacturing Workplaces: An Interdependent Relationship. Int J Ind Ergon. 2004;33(4):295-313. doi: 10.1016/j.ergon.2003.10.002

2. DiDomenico A, Nussbaum MA. Interactive Effects of Physical and Mental Workload on Subjective Workload Assessment. Int J Ind Ergon. 2008;38(11-12):977-983. doi: 10.1016/j. ergon.2008.01.012

3. Farrer Velazquez F, Monaya Lozano G, Niño Escalanta J, Ruiz Napóles M. Manual de ergonomía. Madrid: Fundación MAPFRE; 1994. 
4. Hernandez Arellano JL, Serratos Perez JN, Garcia Alcaraz JL, Maldonado Macias AA. Assessment of Workload, Fatigue, and Musculoskeletal Discomfort Among Computerized Numerical Control Lathe Operators in Mexico. IISE Trans Occup Ergon Hum Factors. 2017;5(2):65-81. doi: 10.1080/24725838.2017.1317301

5. Åhsberg E. Dimensions of Fatigue in Different Working Populations. Scand J Psychol. 2000;41(3):231-241. doi: 10.1111/1467-9450.00192

6. Barker LM, Nussbaum M a. The Effects of Fatigue on Performance in Simulated Nursing Work. Ergonomics. 2011;54(9):815-829. doi: 10.1080/00140139.2011.597878

7. Rashedi E, Kim S, Nussbaum M, Agnew MJ. Ergonomic Evaluation of a Wearable Assistive Device for Overhead Work. Ergonomics. 2014;57(12):1864-1874. doi: 10.1080/00140139.2014.952682

8. Balderrama C, Ibarra G, De La Riva J, López S. Evaluation of Three Methodologies to Estimate the VO2max in People of Different Ages. Appl Ergon. 2010;42(1):162-168. doi: 10.1016/j.apergo.2010.06.017

9. Kim S, Barker LM, Jia B, Agnew MJ, Nussbaum MA. Effects of Two Hospital Bed Design Features on Physical Demands and Usability During Brake Engagement and Patient Transportation: A Repeated Measures Experimental Study. Int J Nurs Stud. 2009;46(3):317-325. doi: 10.1016/j.ijnurstu.2008.10.005

10. Borg G. Ratings of Perceived Exertion and Heart Rates During Short-Term Cycle Exercise and Their Use in a New Cycling Strength Test. Int J Sports Med. 1982;3(3):153-158.

11. DiDomenico A, Nussbaum MA. Interactive Effects of Mental and Postural Demands on Subjective Assessment of Mental Workload and Postural Stability. Saf Sci. 2005;43(7):485495. doi: 10.1016/j.ssci.2005.08.010 